\title{
THE EFFECT OF STORAGE CONDITION ON ANTIOXIDANT ACTIVITY OF PROBIOTICS IN YOGURT DRINKS
}

\author{
JANSEN SILALAHI ${ }^{1 *}$, DARSHIENY NADARASON ${ }^{1}$, YOSY C E SILALAHI ${ }^{2}$
}

${ }^{1}$ Department of Pharmaceutical Chemistry, Faculty of Pharmacy, Nanomedicine Center Universitas Sumatera Utara, Indonesia. ${ }^{2}$ Department of Pharmacy, Faculty of Pharmacy and Health Sciences, Universitas Sari Mutiara, Indonesia. Email: jansen@usu.ac.id

Received: 27 June 2018, Revised and Accepted: 02 August 2018

\section{ABSTRACT}

Objective: The aim of this study was to investigate the effect of temperature and time of storage on antioxidant activity of probiotics in yogurt drinks.

Methods: The samples used were Yakult, Cimory, YoFit, and BioKul marketed in Medan city. The samples were stored at room and refrigerate temperatures for 2 weeks. Various volumes of samples were withdrawn and mixed with $1 \mathrm{ml}$ of 2,2-diphenyl-1-picrylhydrazil solution and homogenized. Then, it was incubated for $30 \mathrm{~min}$ and centrifuged at $5000 \mathrm{rpm}$ for $15 \mathrm{~min}$. The supernatant was collected, and the absorbance was measured at $516 \mathrm{~nm}$ by spectrophotometer. The absorbance of different volume of supernatant of each sample was used to construct linear regression equation. Then, the $\mathrm{IC}_{50}$ value was determined.

Results: The present study shows that the higher the temperature and the longer the time of storage decreased the antioxidant activity of yogurt drinks. Yakult exhibited the highest antioxidant activity among the analyzed samples. Before storage, the $\mathrm{IC}_{50}$ value of Yakult was $0.2763 \mathrm{ml}$, and after stored for 2 weeks, the $\mathrm{IC}_{50}$ value of Yakult was $0.3867 \mathrm{ml}$ at refrigerated and $0.5393 \mathrm{ml}$ at room temperature.

Conclusions: Probiotic in yogurt drinks stored at refrigerated temperature has higher antioxidant activity than stored at room temperature. The $\mathrm{IC}_{50}$ values of yogurt drinks decreased with storage time.

Keywords: Antioxidant, 2,2-diphenyl-1-picrylhydrazil, Probiotics, Storage condition, $\mathrm{IC}_{50}$ value.

(c) 2018 The Authors. Published by Innovare Academic Sciences Pvt Ltd. This is an open access article under the CC BY license (http://creativecommons. org/licenses/by/4. 0/) DOI: http://dx.doi.org/10.22159/ajpcr.2018.v11i12.28156

\section{INTRODUCTION}

Oxidation is an essential process for many living organisms for the production of energy to fuel biological processes. Physiological metabolites such as free radicals and reactive oxygen species (ROS) are formed as a result of respiration in the aerobic organism [1-3]. Formation of free radicals such as superoxide anion radical and hydroxyl radical is unavoidable during respiration, and excessive production can cause damage on lipid, protein, carbohydrate, and nucleic acids $[4,5]$. Fortunately, human body has developed a number of enzymatic and non-enzymatic defense mechanism which can neutralize the free radicals and oxidant molecules [5,6]. In certain circumstances such as chronic hyperglycemia, this antioxidant defense system fails and not effective enough to totally neutralize free radicals which are known as oxidative stress $[2,7]$. Therefore, to prevent the damage by oxidative stress, antioxidant compounds contained in fruits, vegetables, and food supplement containing antioxidant is required to reduce oxidative damage $[4,6,7]$

Probiotic is defined as live microorganisms when administered in adequate amounts, confer a health benefit on the host by improving microbial balance. Probiotic bacteria, especially such as Lactobacillus and Bifidobacterium, are found to be beneficial in preventing the growth of pathogenic bacteria, reducing inflammation, and inhibiting glycation of protein in hyperglycemia. Some bioactive components are produced by probiotic including antioxidants [7-12]. The antioxidant mechanisms of probiotics could be assigned to scavenge ROS by non-enzymatic and enzymatic antioxidants contained in yogurt drinks $[6,13]$. Factors such as $\mathrm{pH}$, redox potential, and acidity, buffering capacity, packaging, molecular oxygen, yogurt composition, and storage time and temperature affect the viability of probiotic bacteria during storage and hence antioxidant activity of yogurt drinks [14,15]. The objective of this study was to examine the effect of the temperature and time of storage on antioxidant activity of probiotics from four plain products of different types/brands of yogurt drinks.

\section{MATERIALS AND METHODS}

\section{Materials}

Reagents and materials were 2,2-diphenyl-1-picrylhydrazil (DPPH), methanol, Vitamin C, and distilled water. The samples used were plain yogurt products purchased from market Pondok Indah Pasar Buah in Jalan Setia Budi, Medan, Indonesia. The samples (plain products) did not contain flavoring agents of four different type/brand yogurt drinks included Yakult, Cimory, YoFit, and BioKul.

\section{Instruments}

Refrigerator, incubator, centrifugation, vortex, analytical balance, and UV-visible Spectrophotometer (Shimadzu UV-1800) and glasswares were used.

\section{Preparation of DPPH solution}

$50 \mathrm{mg}$ of DPPH was transferred into $50 \mathrm{ml}$ of brown volumetric flask and dissolved in methanol and calibrated up to the marked line. From this solution, $2 \mathrm{ml}$ was transferred into $50 \mathrm{ml}$ volumetric flask and added methanol to volume to get a solution of $40 \mu \mathrm{g} / \mathrm{ml}(0.5 \mathrm{mM})[1,16]$

\section{Preparation of Vitamin C solution}

$50 \mathrm{mg}$ of Vitamin C powder was dissolved with methanol in $25 \mathrm{ml}$ brown volumetric flask. From this solution, $2.5 \mathrm{ml}$ was transferred into a $25 \mathrm{ml}$ volumetric flask and added methanol up to the marked line of volumetric flask to make Vitamin C solution with concentration of $200 \mu \mathrm{g} / \mathrm{ml}$. [1,16].

\section{Procedure}

The samples were divided into two groups. Group A samples were stored at cold storage by placing them inside the refrigerator. Group B 
samples were stored at the ambient or room temperature. The samples were stored for 2 weeks, and antioxidant activity was determined before storage, after 1 week, and 2 weeks of storage.

\section{Determination of absorbance curve of DPPH solution}

The DPPH solution with a concentration of $40 \mu \mathrm{g} / \mathrm{ml}$ was transferred into the cuvette and placed into the spectrophotometer. The absorbance was measured within the wavelength between 400 to $800 \mathrm{~nm}$ to get absorbance curve. From this absorbance curve, the maximum absorbance of DHHP solution was found to be $516 \mathrm{~nm}$ and used in this study.

DPPH free radical scavenging assay of Vitamin $C$ and tested samples

$1 \mathrm{ml}$ of methanolic DPPH solution $(40 \mu \mathrm{g} / \mathrm{ml})$ was transferred into a volumetric flask of $5 \mathrm{ml}$ and added $0.0625 \mathrm{ml}$ Vitamin $\mathrm{C}$ solution of $200 \mu \mathrm{g} / \mathrm{ml}$; the same procedure was carried out with $0.1250 \mathrm{ml}$, $0.2500 \mathrm{ml}$, and $0.500 \mathrm{ml}$ of Vitamin C solution. This procedure also applied to each yogurt drink with a series of volumes, namely $0.25 \mathrm{ml}$, $0.50 \mathrm{ml}, 0.75 \mathrm{ml}$, and $1.0 \mathrm{ml}$ of Yakult, Cimory, YoFit, and BioKul, respectively, then methanol was added to each mixture to the volume of $5 \mathrm{ml}$ (to the marked line). It was well vortexed, and then incubated for $30 \mathrm{~min}$ at room temperature. The samples were centrifuged for $15 \mathrm{~min}$ at $5000 \mathrm{rpm}$. The supernatant was collected, and the absorbance of the sample was measured at $516 \mathrm{~nm}$ using the spectrophotometer. Negative control was prepared using $1.0 \mathrm{ml}$ of DPPH solution transferred into $5 \mathrm{ml}$ volumetric flask and added methanol to volume without addition of the sample. It was allowed to stand for $30 \mathrm{~min}$ at room temperature then the absorbance (A) was measured. The readings were recorded in triplicates. The percentage of radical scavenging activity (RSA) was calculated:

$\mathrm{RSA}(\%)=\frac{\mathrm{A}(\text { control })-\mathrm{A}(\text { sample })}{\mathrm{A}(\text { control })} \times 100$

Graphs for the effect of storage condition of samples and Vitamin C on DPPH scavenging activity (\%) were plotted, and the regression equation determined $[1,17]$.

\section{Determination of IC $_{50}$ value}

The effective volume of Vitamin $\mathrm{C}$ and samples required to scavenge DPPH radical by $50 \%$ (IC $_{50}$ value) was obtained from linear regression analysis of dose-response curve obtained by plotting between percentage inhibition and volume (ml). The results obtained from the DPPH scavenging activity were substituted into the regression equation, where the X-axis was the volume of vitamin $\mathrm{C}$, and Y-axis was the percentage of DPPH scavenging activity [17].

Determination of $\mathrm{IC}_{50}$ from regression equation; $\mathrm{Y}=\mathrm{aX}+\mathrm{b}$

Notes: $\mathrm{Y}=$ Percentage of $\mathrm{DPPH}$ scavenging activity $\left(\mathrm{IC}_{50}\right.$, dependent variable); $\mathrm{a}=$ Slope/gradient; $\mathrm{x}=$ Volume of vitamin $\mathrm{C}$ (independent variable); $b=$ intercept.

\section{RESULTS AND DISCUSSION}

\section{Absorbance curve of DPPH solution}

The absorbance measurement of the DPPH solution in methanol using a UV-visible spectrophotometer and the absorbance curve is presented in Fig. 1.

From Fig. 1, the maximum absorbance of the DPPH solution is at the wavelength of $516 \mathrm{~nm}$ and used to determine $\mathrm{IC}_{50}$.

\section{DPPH scavenging activity (\%) of yogurt drinks}

The effect of storage condition of each sample on DPPH scavenging activity (\%) can be seen in Figs. 2-5. The scavenging activity percentage of Vitamin C is shown in Fig. 6.

Regression equation from Figs. 2-6 was used to calculate the $\mathrm{IC}_{50}$ value of each sample. From Figs. 2-5 can be seen that the scavenging percentage of the all samples decreased with the storage time. The prominent decreased in scavenging percentage can be observed in storage at room temperature compared to the refrigerate temperature.

Figs. 2-6 show that the lower the absorbance value of DPPH solution mixed with sample the higher antioxidant activity of the analyzed samples. This is due to the ability of Vitamin $\mathrm{C}$ and bioactive components produced by probiotic to chemically reduce DPPH solution which is used to evaluate the antioxidant activity. Interaction of antioxidant compounds with DPPH is based on the transfer of hydrogen atom to DPPH radical and converts it into DPPH-H. The result of the reduction of DPPH radicals results in color change from a purple color to yellow pale color which indicates the antioxidant activity of the sample $[7,18]$.

\section{Antioxidant activity of Vitamin $\mathrm{C}$ and yogurt drinks}

The $\mathrm{IC}_{50}$ value of the samples and Vitamin $\mathrm{C}$ was determined using linear regression equation obtained by plotting the volume of test samples as $\mathrm{X}$-axis and the scavenging percentage of tested samples as $\mathrm{Y}$-axis. The $\mathrm{IC}_{50}$ value was determined by calculating the volume that required to scavenge $50 \%$ of DPPH radicals by the samples. The result of IC $\mathrm{C}_{50}$ value can be seen in Fig. 7. From Fig. 7 can be seen that the smaller the volume of tested sample the higher the antioxidant activity indicate that the lower volume needed to scavenge DPPH solution at $50 \%$ and stated or called as $\mathrm{IC}_{50}$ and vice versa.

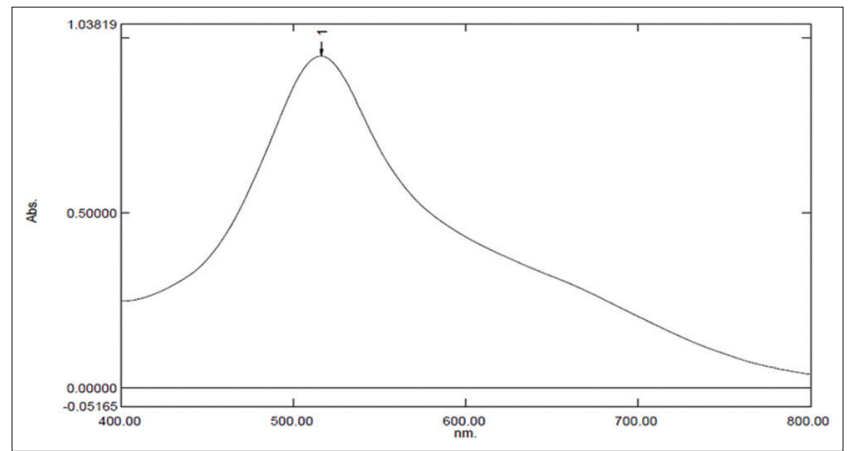

Fig. 1: Absorbance curve of 2,2-diphenyl-1-picrylhydrazil solution in methanol $(40 \mu \mathrm{g} / \mathrm{ml})$

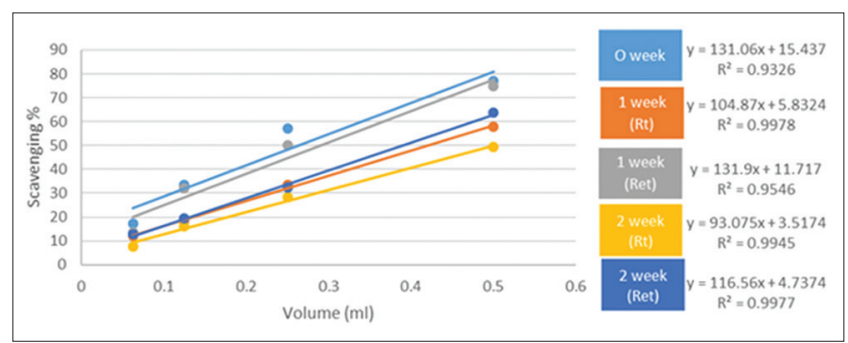

Fig. 2: The effect of storage condition of Yakult on 2,2-diphenyl1-picrylhydrazil scavenging activity (\%). Rt: Room temperature; Ret: Refrigerator temperature

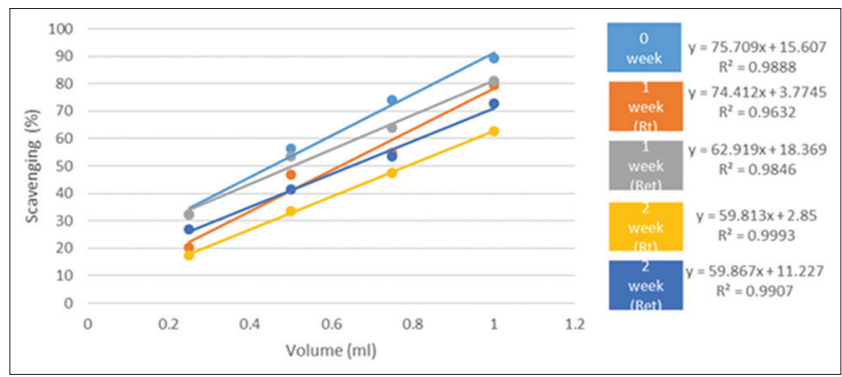

Fig. 3: The effect of storage condition of Cimory on 2,2-diphenyl1-picrylhydrazil scavenging activity (\%). Rt: Room temperature; Ret: Refrigerator temperature 


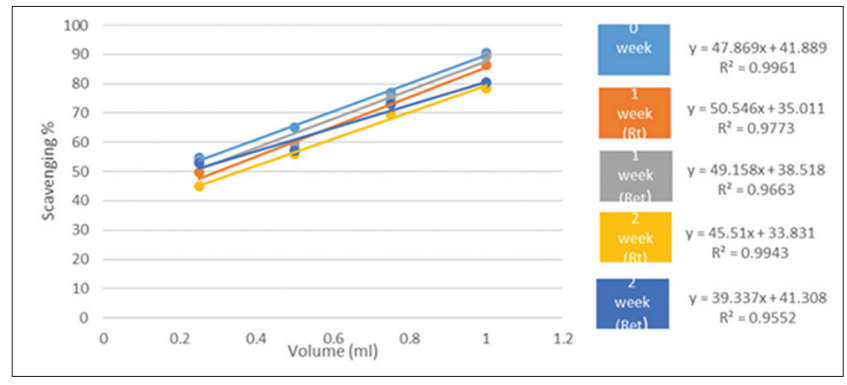

Fig. 4: The effect of storage condition of YoFit on 2,2-diphenyl-1picrylhydrazil scavenging activity (\%). Rt: Room temperature; Ret: Refrigerator temperature

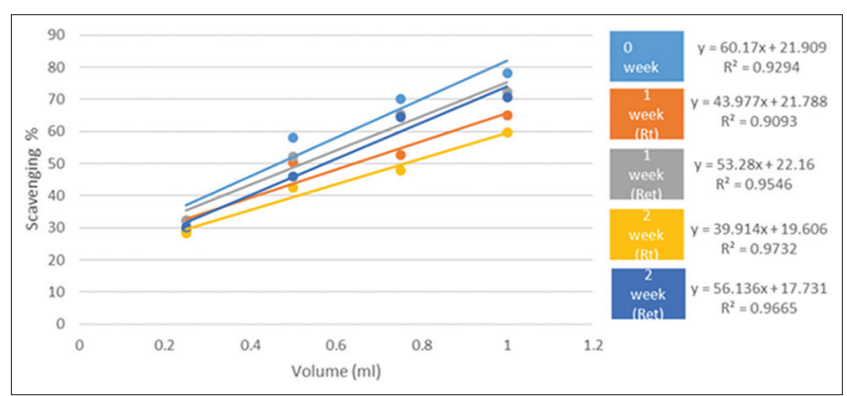

Fig. 5: The effect of storage condition of BioKul on 2,2-diphenyl1-picrylhydrazil scavenging activity (\%). Rt: Room temperature; Ret: Refrigerator temperature

The $\mathrm{IC}_{50}$ value decreased with storage time for both room and refrigerates temperature. Before storage, $\mathrm{IC}_{50}$ value of Yakult $(0.2763 \mathrm{ml})$ is the highest value followed by YoFit, Cimory, and BioKul to scavenge the DPPH radicals by $50 \%$. Even after storage at room and refrigerate temperature, Yakult has the highest $\mathrm{IC}_{50}$ value compared to other samples. Vitamin $\mathrm{C}$ with concentration of $2.5 \mathrm{ug} / \mathrm{ml}$ as positive control of antioxidant was found to be the strongest antioxidant with $\mathrm{IC}_{50}$ value of $0.1742 \mathrm{ml}$ which is much higher than Yakult $[19,20]$.

Probiotics demonstrate antioxidant activity by secreting enzymes such as superoxide dismutase (SOD) and promote the production of the major non-enzymatic antioxidant and free radical scavenger glutathione (GSH). SOD catalyzes the breakdown of superoxide into hydrogen peroxide and water. Thus, it acts as a central regulator of ROS levels. GSH eliminates radicals such as hydrogen peroxides, and hydroxyl radicals, by collaborating with selenium-dependent GSH peroxidase $[16,21]$. Probiotics also promote the production of certain antioxidant biomolecules, such as the exopolysaccharides [11]. In addition, antioxidant activity could also be due to metal chelating activity, but the mechanism is still unclear $[16,21]$.

Although Yakult has the shortest expiry date compared to others, Yakult exerted the highest scavenging percentage followed by YoFit, Cimory, and BioKul in both room and refrigerate temperature for 2 weeks. For Yakult, only small volume was withdrawn to react with DPPH solution because Yakult expressed high scavenging percentage in very small volume $(0.0625 \mathrm{ml})$ before and after storage in both room and refrigerate temperature for 2 weeks compared to other samples (Cimory, YoFit, and BioKul). Several factors affecting survival of the probiotic bacteria and thus the antioxidant activities include storage temperature, composition of food, type of packaging materials, moisture content of powders, oxygen content, and exposure to light. [22]. The species and number of probiotic bacteria present in the products could also affect the viability of bacteria during storage and hence the ability to produce the bioactive components including antioxidant peptides [1]. In this study, Lactobacillus casei (L. casei shirota) is the only probiotic present in Yakult products as mentioned on the label.

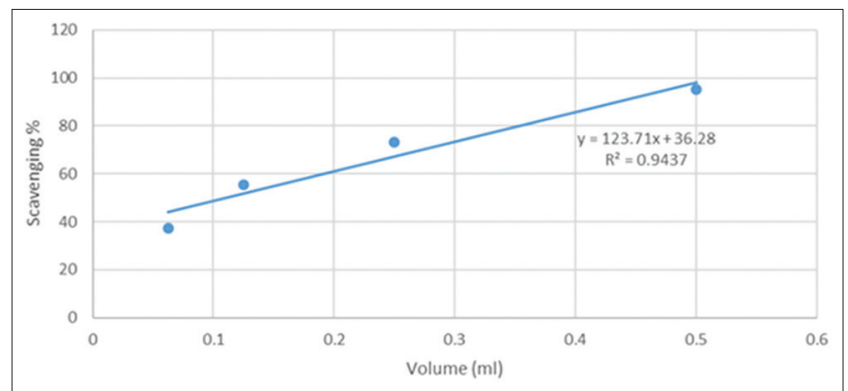

Fig. 6: 2,2-diphenyl-1-picrylhydrazil scavenging activity (\%) of Vitamin C $2.5 \mu \mathrm{g} / \mathrm{ml}$

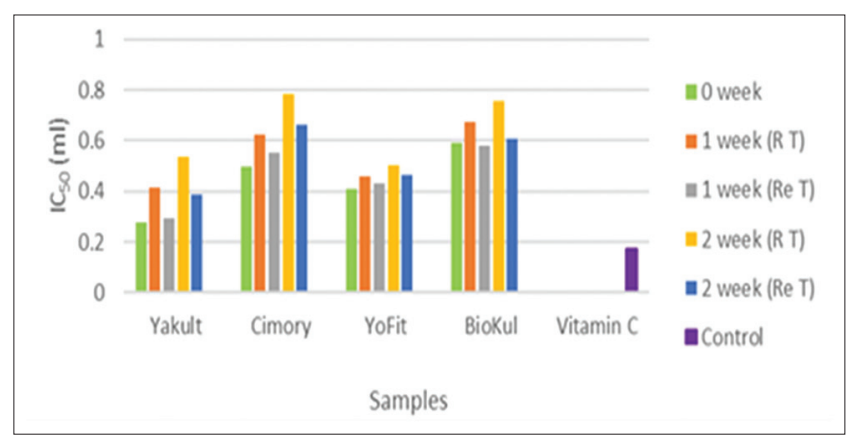

Fig. 7: Antioxidant activity ( $\mathrm{IC}_{50}$ ) of samples and Vitamin C. RT: Room temperature; ReT: Refrigerator temperature

The other samples contain more than one probiotic bacteria as written on the label. Cimory contains two probiotic bacteria, Streptococcus thermophylus and Lactobacillus delbrueckii subsp. bulgaricus. BioKul contains four probiotics, Streptococcus thermophylus and Lactobacillus bulgaricus, Lactobacillus acidophilus and Bifidobacterium, and Yofit contains L. acidohpilus LA-5, Bifidobacterium BB12, and Streptococcus thermophilus.

The antioxidant activity of probiotic bacteria in yogurt drinks is inversely related to the storage temperature. Food that contain probiotics preferably stored at a temperature of $2-8^{\circ} \mathrm{C}[22,23]$. This is because storage above $20^{\circ} \mathrm{C}$ for prolong duration of time decreases the viability of certain probiotic bacteria such as L. acidophilus and Bifidobacterium lactis. Thus, the decrease in the viability of bacteria could decrease the antioxidant activity of probiotic bacteria that present in yogurt drinks at room temperature as can be seen from the data that the scavenging percentage decrease for all the samples at $1^{\text {st }}$ and $2^{\text {nd }}$ week of storage. The common probiotics that present in all the samples is L. acidophilus and $B$. lactis. Hence, the most suitable temperature for the viability of L. acidophilus is $2^{\circ} \mathrm{C}$ and B. lactis is $4^{\circ} \mathrm{C}[23]$.

Yakult has the shortest expiry followed by Cimory, YoFit, and BioKul with the longest expiry. Addition of growth promotors such as glucose, vitamins, minerals, casein, whey protein, yeast extract, and antioxidants are fortified in dairy products to increase the viability of the probiotics. Oxygen content and redox potential are harmful to the probiotic survival during storage because most of the species are anaerobic and saccharolactic [22]. Free radicals produced from the oxidation of components (e.g., fat and sugar) can be hazardous to the probiotics. Therefore, the level of oxygen during packaging should be as low as possible, because all the tested samples in this study contain sucrose and skim milk powder in their composition, which may produce free radicals during storage; thus, the scavenging activity also decreases on the storage $[22,23]$.

Packaging aspects such as type and thickness of the materials, gas (oxygen, carbon dioxide, and water vapor) and light permeability 
may also influence the survival of the probiotics. The surrounding temperature may affect gas permeability through the container and thereby affect the survival of the probiotics. Therefore, the use of plastic films with high oxygen barrier properties or packaging with oxygen absorbers can prolong the survival of probiotics during storage and thereby increase the antioxidant properties $[22,23]$.

\section{CONCLUSION}

Storage at refrigerate temperature $\left(4^{\circ} \mathrm{C}-10^{\circ} \mathrm{C}\right)$ has higher antioxidant activity compared to the storage at room temperature, and antioxidant activities decrease with time of storage. Yakult has the highest antioxidant activity compared to other tested yogurt drinks but still lower compared with Vitamin C.

\section{AUTHORS CONTRIBUTION}

Jansen conceived the study and was in charge of overall direction and planning and supervised the work. Darshieny Nadarason was involved in planning and performed the experiments. Yosy C E Silalahi contributed in the experimental design, collected and analyzed the data, and wrote the manuscript with input from all authors.

\section{CONFLICTS OF INTEREST}

No conflicts of interest are associated with this work.

\section{REFERENCES}

1. Unal G, El SN, Akalin AS, Dinkci N. Antioxidant activity of probiotic yoghurt fortified with milk protein based ingredients. Ital J Food Sci 2013;25:63.

2. Toro J, Rodrigo R. Oxidative stress: Basic overview. In: Rodrigo R, editor. Oxidative Stress and Antioxidants: Their Role in Human Disease. New York: Nova Science Publishers, Incorporated.; 2009. p. $1-12$.

3. Nunes XP, Silva FS, Almeida JR, de Lima JT, de Araújo Ribeiro LA, Júnior LJ, et al. Biological oxidations and antioxidant activity of natural products. In: Rao V, editor. Phytochemicals as Nutraceuticals-Global Approaches to Their Role in Nutrition and Health. Croatia: InTech; 2012. p. 1-20.

4. Virtanen T, Pihlanto A, Akkanen S, Korhonen H. Development of antioxidant activity in milk whey during fermentation with lactic acid bacteria. J Appl Microbiol 2007;102:106-15.

5. Kleniewska P, Hoffmann A, Pniewska E, Pawliczak R. The influence of probiotic Lactobacillus casei in combination with prebiotic inulin on the antioxidant capacity of human plasma. Oxid Med Cell Longev 2016;2016:1340903.

6. Amaretti A, di Nunzio M, Pompei A, Raimondi S, Rossi M, Bordoni A, et al. Antioxidant properties of potentially probiotic bacteria: In vitro and in vivo activities. Appl Microbiol Biotechnol 2013;97:809-17.
7. Patil RS, Jagdale AD, Nalawade ML, Bavkar LN, Akalpita U. Glycation inhibitors and probiotics can ameliorate the changes caused by high fructose feed. Int J Pharm Pharm Sci 2018;10:28-32.

8. Priscilla MA, Periyar SS, Seema AK. Isolation and characterization of potential probiotics from fermented ragi (Elusine Coracana). Int J Pharm Pharm Sci 2018;10:145-51.

9. Persichetti E, De Michele A, Codini M, Traina G. Antioxidative capacity of lactobacillus fermentum LF31 evaluated in vitro by oxygen radical absorbance capacity assay. Nutrition 2014;30:936-8.

10. Ejtahed HS, Mohtadi-Nia J, Homayouni-Rad A, Niafar M, AsghariJafarabadi M, Mofid V, et al. Probiotic yogurt improves antioxidant status in Type 2 diabetic patients. Nutrition 2012;28:539-43.

11. Afify AE, Romeilah RM, Sultan SI, Hussein MM. Antioxidant activity and biological evaluations of probiotic bacteria strains. Int J Acad Res 2012;4:131-9.

12. Grajek W, Olejnik A, Sip A. Probiotics, prebiotics and antioxidants as functional foods. Acta Biochim Pol 2005;52:665-71.

13. Duda-Chodak A, Tarko T, Statek M. The effect of antioxidants on Lactobacillus casei cultures. ACTA Sci Pol Technol Aliment 2008;7:39-51.

14. Ferdousi R, Rouhi M, Mohammadi R, Mortazavian AM, KhosraviDarani K, Homayouni Rad A, et al. Evaluation of probiotic survivability in yogurt exposed to cold chain interruption. Iran J Pharm Res 2013;12:139-44.

15. Gueimonde M, Delgado S, Mayo B, Ruas-Madiedo P, Margolles A, de los Reyes-Gavilán C G. Viability and diversity of probiotic Lactobacillus and Bifidobacterium populations included in commercial fermented milks. Food Res Int 2004;37:839-50.

16. Kim HS, Chae HS, Jeong SG, Ham JS, Im SK, Ahn CN, et al. Antioxidant activity of some yogurt starter cultures. Asian Aust J Anim Sci 2005; 18:255-8

17. Freitas R, Miranda RO, Netto GG, Nero LA, Carvalho AF Interference of different storage temperatures in the dynamics of probiotic Bifidobacterium spp. and Streptococcus thermophilus starter cultures in fermented milk. Arquivos do Instituto Biol 2015;82:1-4.

18. Dontha S. A review on antioxidant methods. Asian J Pharm Clin Res 2016;9 suppl.2:14-32.

19. Oh CW, Li M, Kim EH, Park JS, Lee JC, Ham SW. Antioxidant and radical scavenging activities of ascorbic acid derivatives conjugated with organo germanium. Bull Korean Chem Soc 2010;31:3513-4

20. Dumbravă D, Moldovan C, Raba DI, Popa M. Comparative analysis of vitamin C content and antioxidant activity of some fruits extracts. J Agrol ProcTechnol 2012;18:223-8.

21. Wang Y, Wu Y, Wang Y, Xu H, Mei X, Yu D, et al. Antioxidant properties of probiotic bacteria. Nutrients 2017;9: pii: E521.

22. Tripathi MK, Giri SK. Probiotic functional foods: Survival of probiotics during processing and storage. J Funct Foods 2014;9:225-41.

23. Nadal ES, Sayas-Barberá E, Fernández-López J, Pérez-Alvarez JA. Food formulation to increase probiotic bacteria action or population. In: Watson RS, Preedy VR, editors. Bioactive Foods in Promoting Health: Probiotic and Prebiotics. London: Elsevier; 2010. p. 335-51. 